BMJ Open Sport \& Exercise Medicine

\title{
Injuries among Maryland jockeys during thoroughbred racing: 2015-2019
}

\author{
Kelly Ryan, ${ }^{1}$ Gabrielle Garruppo, ${ }^{2}$ Kezia Alexander (1) , ${ }^{3}$ Christine M Hluchan, ${ }^{4}$ \\ Andrew E Lincoln (1) ${ }^{3,5}$
}

To cite: Ryan K, Garruppo G, Alexander K, et al. Injuries among Maryland jockeys during thoroughbred racing: 2015-2019. BMJ Open Sport \& Exercise Medicine 2020;6:e000926. doi:10.1136/ bmjsem-2020-000926

Accepted 12 November 2020

Check for updates

C) Author(s) (or their employer(s)) 2020. Re-use permitted under CC BY-NC. No commercial re-use. See rights and permissions. Published by BMJ.

${ }^{1}$ Family Medicine, MedStar Franklin Square Medical Center, Baltimore, Maryland, USA

${ }^{2}$ Johns Hopkins University Bloomberg School of Public Health, Baltimore, Maryland, USA

${ }^{3}$ MedStar Sports Medicine Research Center, MedStar Health Research Institute, Hyattsville, Maryland, USA ${ }^{4}$ Johns Hopkins University School of Medicine, Baltimore, Maryland, USA

${ }^{5}$ Rehabilitation Medicine, Georgetown University Medical Center, Washington DC, District of Columbia, USA

Correspondence to Dr Kelly Ryan; kelly.d.ryan@medstar.net

\section{ABSTRACT}

Objectives Our goal was to characterise jockey injuries at Maryland racetracks during thoroughbred racing activities over 4 years using medical records maintained by the sports medicine team.

Methods Injury data were prospectively gathered by sports medicine physicians who were onsite for all thoroughbred racing activities in Maryland from 12 September 2015 to 5 May 2019 to evaluate and treat any injury to the jockeys. Descriptive statistics (frequencies, rates with corresponding 95\% Cls and proportions) of injury types, body parts, mechanisms, severity and location on track were calculated.

Results Over nearly 4 years of racing and 45000 mounts, there were 204 injuries involving 184 incidents and 131 falls during those races. The vast majority of injuries $(80 \%)$ was related to soft tissue, while $4 \%$ were concussions. Most injuries involved the lower extremity (31\%) or upper extremity (26\%) and typically resulted from a fall from the horse. Among all incidents, $79.3 \%(n=146)$ resulted in an injury, while $76.3 \%(n=100)$ of falls resulted in an injury. We identified a significant proportion of injuries $(41 \%)$ in and around the starting gate. Over a quarter of incidents resulting in injury required further medical care in hospital or other medical facility, while surgery was required in $2.5 \%$ of injuries.

Conclusion Access to a consistent group of sports medicine providers facilitated jockey injury reporting and tracking. The majority of jockey injuries is related to soft tissue and results from falls, while the starting gate area is associated with the greatest proportion of injuries.

\section{INTRODUCTION}

Thoroughbred horse racing is one of the most competitive and popular sports worldwide, but it is very physically demanding and not without substantial risk. ${ }^{1}$ Jockeys are elite athletes who sit perched atop an animal weighing 10 times their mass while galloping at speeds up to $64 \mathrm{~km} / \mathrm{h}(40 \mathrm{mph}) .^{2}$ A single misstep or slight error may result in the jockey being thrown from the horse, potentially resulting in catastrophic injury or death. ${ }^{2}$ While most reported injuries have been associated with falls, ${ }^{3-7}$ there are also injuries that can result from training activities or simply being in close proximity to a horse. ${ }^{8}$
What are the new findings?

- Jockeys sustained 4.5 injuries per 1000 mounts $(95 \% \mathrm{Cl} 3.9$ to 5.1$), 36.4$ injuries per 1000 races $(95 \% \mathrm{Cl} 31.4$ to 41.4$)$ and 345.8 injuries per 1000 race days.

- The vast majority of injuries $(80 \%)$ was related to soft tissue, while $4 \%$ was concussions.

- The majority of injuries involved the lower extremity $(31 \%)$ or upper extremity $(26 \%)$ and typically resulted from a fall from the horse.

- Ease of access to a consistent group of medical providers facilitated improved reporting, especially of minor injuries.

- The rate of fractures in our study (145 per 1000 falls) was significantly higher than rates reported elsewhere.

How might it impact on clinical practice in the future?

Sports medicine clinicians and racing tracks/jurisdictions should coordinate care and work to improve injury data collection to benefit riders' health and safety internationally.

- A quarter of injuries required additional care beyond the racetrack necessitating a coordination of care between emergent care, imaging, rehabilitation services and specialty care.

Professional horse racing requires jockeys to train year-round and compete at high levels in front of millions of viewers, yet they are often under-recognised as athletes, particularly in the USA. This is evident by the sparse medical care typically involved at US racetracks, outside of emergency medical services. There are varying medical models among racing organisations around the world, which implement a range of practices for injury reporting and management. ${ }^{8}$ Our field relies on consistent injury surveillance platforms to identify patterns and develop interventions to improve safety among athletes in specific sports, including jockeys. Unfortunately, with inconsistent reporting of injuries, 
comparisons across countries to identify and adopt best practices are challenging.

The Maryland Jockey Club is the oldest professional sports organisation in the USA. ${ }^{9}$ In 2015, it developed the Horsemen's Health Program, which implemented primary care sports medicine physicians to provide medical coverage at the racetracks across the state. Maryland racetracks operate year-round, with approximately 160 racing days per year, averaging 200 riders annually, usually between 20-35 jockeys riding per day, throughout the state. Maryland only races one track in the state at any given time.

Most jockey injury studies involving flat racing were performed in the UK and Australia. ${ }^{4-13}$ and most recently a study analysing injuries endured during the 'Palio', the oldest horserace in Italy. There have been studies of jockey injuries in California ${ }^{2}$ and on overall jockey injuries in the USA. ${ }^{14}$ However, there are no studies that characterise jockey injuries on the East Coast. Our goal was to characterise jockey injuries at Maryland racetracks during racing activities over the past 4 years using medical records maintained by the sports medicine team.

\section{METHODS}

Clinical data were documented by sports medicine physicians who were onsite for all thoroughbred racing activities in Maryland from 12 September 2015 to 5 May 2019 to evaluate and treat any injury to the jockeys. Our definition of injury was consistent with the European Consensus statement, which includes 'any physical complaint sustained by a person that results from competitive riding, training or other recognised activity that brings a person into contact, or in the close vicinity and with the potential for contact, with one or more thoroughbred race horses, irrespective of the need for medical attention or time loss from horse racing activities' ${ }^{8}$ A fall was defined as 'a rider being dislodged from a horse, regardless of its outcome'. ${ }^{12}$ 'Incident' was defined as an event that occurred involving the jockey that required enough of a concern or risk of resultant injury that the rider needed an evaluation and injury report to be completed by the racetrack physician. The number of participating jockeys, mounts, races and race meetings during the study period were provided by the Maryland Jockey Club and the InCompass system (Lexington, Kentucky, USA).

For each incident, a Maryland First Report of Accident form was completed by a physician, which included information about the type of injury sustained, the body part involved, the location on the track and a narrative text description of the incident. Additional medical information may have been added to the initial report based on medical records resulting from any transfer to hospital.

Descriptive statistics (frequencies, rates with corresponding 95\% CIs, and proportions) of injury types, body parts, mechanisms, severity and location on track were calculated. Data were analysed using Microsoft Excel, V.16.11.1 (Redmond, Washington, USA).

This study and overall injury surveillance efforts were supported by the Maryland Jockey Club and the Maryland Thoroughbred Horsemen's Association. This study was approved by MedStar Health's Institutional Review Board.

\section{Patient and public involvement}

Patients and/or the public were not involved in the design, or conduct, or reporting or dissemination plans of this research.

\section{RESULTS}

There were 670 participating jockeys across Maryland racetracks, including 383 at Laurel Park, 191 at Pimlico and 96 at Timonium, many of whom ride at multiple tracks. There were 590 race days with 5611 races and 45284 mounts at the three Maryland racetracks from 12 September 2015 to 5 May 2019. During that time, there were 131 falls, 184 incidents and 204 injuries (table 1). Among all incidents, $79.3 \%(\mathrm{n}=146)$ resulted in an injury, while $76.3 \%(\mathrm{n}=100)$ of falls resulted in an injury.

Jockeys sustained 4.5 injuries per 1000 mounts (95\% CI 3.9 to 5.1$)$, 36.4 injuries per 1000 races $(95 \%$ CI 31.4 to 41.4 ) and 345.8 injuries per 1000 race days (95\% CI 298.3 to 393.2) (table 1). Soft tissue injuries were the most commonly reported, with 163 of our 204 total injuries $(79.9 \%)$. Hematomas, contusions and bruises $(52.4 \%$, $\mathrm{n}=107$ ) were the most common injuries, followed by strains and sprains $(19.1 \%, \mathrm{n}=39)$, fractures $(9.3 \%, \mathrm{n}=19)$ and abrasions and lacerations $(8.3 \%, \mathrm{n}=17$ ) (table 2). Out of 22 total head injuries, 8 were concussions $(3.9 \%$ of injuries, 0.18 per 1000 mounts (95\% CI 0.05 to 0.30$)$ ). Six of the concussions resulted from a fall from the horse and two from being headbutted by the horse.

The most common body parts injured were the lower extremity (30.9\%), upper extremity $(25.5 \%)$, head $(15.2 \%)$ and shoulder $(11.8 \%)$ (figure 1). The most common mechanisms of injury were being thrown from the horse $(23.3 \%)$, a horse that reared or was spooked $(16.4 \%)$, a horse breakdown $(16.4 \%)$ and impact with gate/fence/rail (11.6\%) (table 3 ).

Three-fourths $(n=153)$ of the total injuries were sustained from a fall from the horse, corresponding to 1.1 injuries per fall and one fall occurring every 4.6 race days. There were 2.9 falls per 1000 mounts, or 1 fall per 357 mounts. Of these falls, $4.6 \%$ resulted in concussion. Further, 18 of the 19 fractures were the result of a fall ( 145.0 fractures per 1000 falls (95\% CI 79.8 to 210.3))

The track location where the largest proportion of injuries occurred was the vicinity of the starting gate (ie, in the gate, leaving the gate or prior to entering the gate) $(41.1 \%)$ (figure 2$)$. The other common locations were in the homestretch $(14.4 \%)$, immediately postfinish $(8.2 \%)$ and near the finish line $(6.8 \%)$.

In terms of further medical care, 20 jockeys $(14.0 \%$ of incidents resulting in injury) required immediate 
Table 1 Maryland thoroughbred jockey exposures and events, 2015-2019

\begin{tabular}{|c|c|}
\hline Exposures & Frequency \\
\hline Race days & 590 \\
\hline Races & 5611 \\
\hline Mounts & 45284 \\
\hline Jockeys & 670 \\
\hline \multicolumn{2}{|l|}{ Events } \\
\hline Incidents* & 184 \\
\hline Incidents resulting in injury & $146(79.3 \%)$ \\
\hline Fallst & 131 \\
\hline Falls resulting in injury & $100(76.3 \%)$ \\
\hline Injuriesł & 204 \\
\hline Transfers to hospital & 20 \\
\hline \multirow[t]{2}{*}{ Transfers to other medical facility } & 21 \\
\hline & Incidence $(95 \% \mathrm{Cl})$ \\
\hline \multicolumn{2}{|l|}{ Incidents } \\
\hline Per 1000 race days & $\begin{array}{l}306.8 \text { (266.8 to } \\
356.9)\end{array}$ \\
\hline Per 1000 races & 32.8 (28.1 to 37.5$)$ \\
\hline Per 1000 mounts & 4.1 (3.5 to 4.7$)$ \\
\hline \multicolumn{2}{|l|}{ Falls } \\
\hline Per 1000 race days & $\begin{array}{l}222.0 \text { (184.0 to } \\
260.1)\end{array}$ \\
\hline Per 1000 races & 23.3 (19.3 to 27.3 ) \\
\hline Per 1000 mounts & 2.9 (2.4 to 3.4$)$ \\
\hline \multicolumn{2}{|l|}{ Injuries } \\
\hline Per fall & $1.2(1.0$ to 1.4$)$ \\
\hline Per 1000 race days & $\begin{array}{l}345.8 \text { (298.3 to } \\
393.2)\end{array}$ \\
\hline Per 1000 races & 36.4 (31.4 to 41.4$)$ \\
\hline Per 1000 mounts & 4.5 (3.9 to 5.1$)$ \\
\hline
\end{tabular}

*Incident: an event that occurred involving the jockey that required enough of a concern or risk of resultant injury that the rider needed an evaluation and injury report to be completed by the racetrack physician.

†Fall: a rider being dislodged from a horse, regardless of its outcome. $^{12}$

‡Injury: any physical complaint sustained by a person that results from competitive riding, training, or other recognised activity that brings a person into contact, or in the close vicinity and with the potential for contact, with one or more thoroughbred race horses, irrespective of the need for medical attention or time loss from horse racing activities. ${ }^{8}$

transport to a hospital by ambulance $(0.4$ ambulance transfers per 1000 mounts, 95\% CI 0.2 to 0.6$)$. An additional 21 jockeys $(14.4 \%$ of incidents resulting in injury) were transferred to another medical facility for further evaluation at an orthopaedic clinic, urgent care centre or imaging centre $(0.5$ transfers per 1000 mounts, $95 \%$ CI 0.3 to 0.7$)$. There were nine total surgeries, including two cases of internal bleeding from
Table 2 Type of injury $(n=204)$

\begin{tabular}{lcc} 
Type of injury & Frequency & Percentage \\
\hline Hematoma/contusion/bruise & 107 & 52.4 \\
Strain/sprain & 39 & 19.1 \\
\hline Fracture & 19 & 9.3 \\
Abrasion/laceration & 17 & 8.3 \\
Concussion & 8 & 3.9 \\
Generalised pain & 4 & 2.0 \\
Visceral injury & 3 & 1.5 \\
Dental injury & 3 & 1.5 \\
Dislocation/subluxation & 2 & 1.0 \\
Ligament tear & 2 & 1.0 \\
Total & 204 & 100 \\
\hline
\end{tabular}

a splenic laceration, a case of questionable oesophageal perforation and an unusual case of an anterior cruciate ligament (ACL) repair not diagnosed on initial evaluation, but later required intervention. Other surgical cases included a radial collateral ligament tear, distal fibula open reduction internal fixation, two shoulder labral/tendon repairs and a metacarpal fracture repair.

\section{DISCUSSION}

The goal of this study was to characterise the rate, types and mechanisms of injury among jockeys at Maryland thoroughbred racetracks. Over nearly 4 years of racing and 45000 mounts, there were 204 injuries involving 184 incidents and 131 falls during those races. The vast majority of injuries $(80 \%)$ was related to soft tissue, while $4 \%$ was concussions. The majority of injuries involved the lower extremity (31\%) or upper extremity (26\%) and typically resulted from a fall from the horse. Over a quarter of incidents resulting in injury required further medical care in hospital or other medical facility, while surgery was required in $2.5 \%$ of injuries.

\section{Falls}

Our study identified one fall per 357 mounts, with $75.6 \%$ of falls resulting in injury. In contrast, O'Connor et al reported one fall per 250 mounts with $35 \%$ of these resulting in injury at the Irish Turf Club, ${ }^{7}$ while a study in Ireland, France and Britain reported one fall per 227-370 mounts with $40 \%-59 \%$ resulting in injury. ${ }^{11}$ In California, Hitchens et al reported one fall per 200 mounts. ${ }^{3}$ In Australia, from 2002 to 2006, the rate was one fall in 238 mounts. ${ }^{12}$ To provide some context, Hitchens reported that jockeys participated in a median of 160.5 mounts during this time period, so likely experienced at least one fall in that time.

Such variations in rates are likely influenced by differences in injury reporting, including the definition of a fall or injury. Some studies limited the case definition of injuries to those requiring hospitalisation or time off from racing, ${ }^{3} 11-131516$ while others included only 


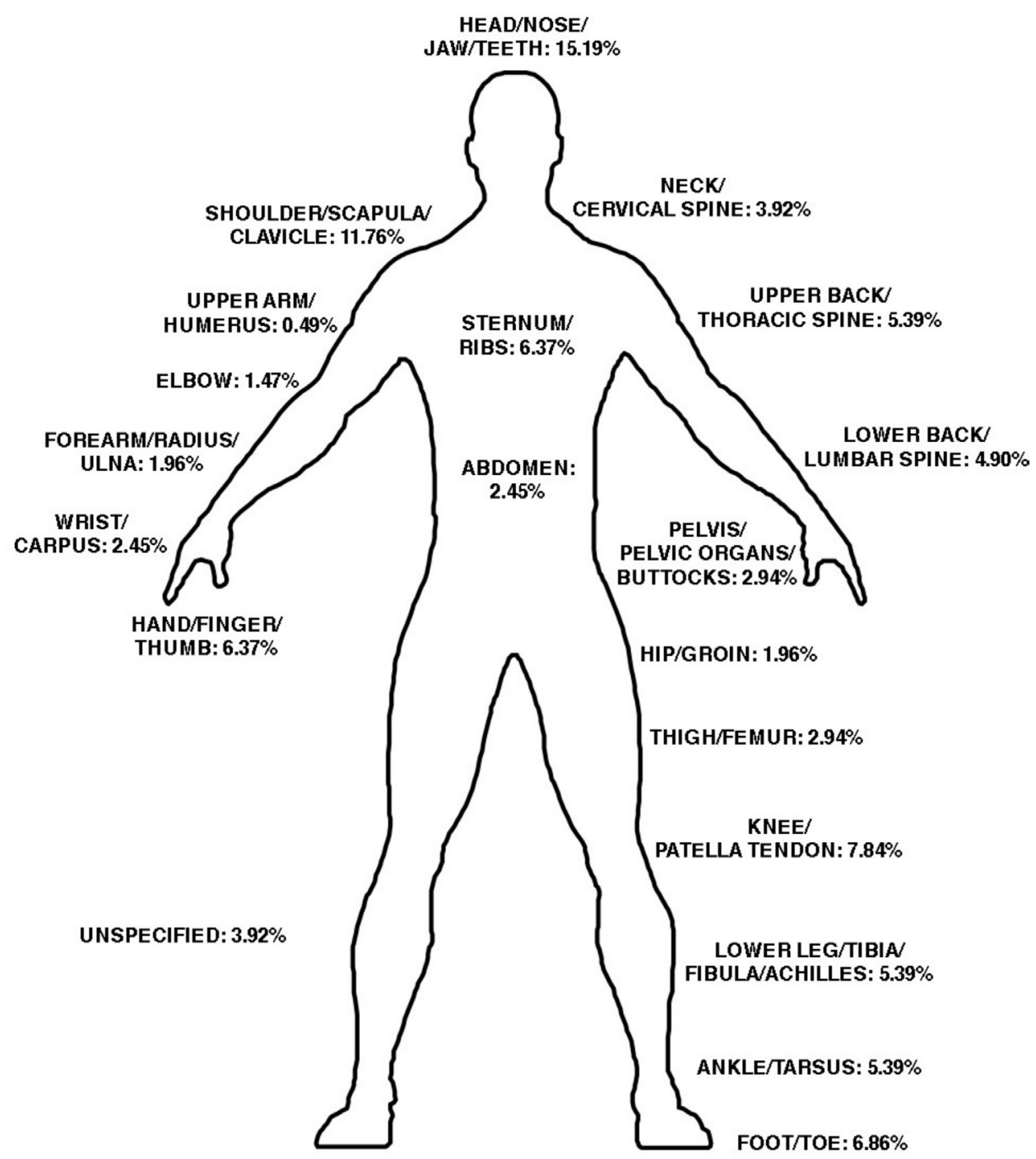

Figure 1 Injury by body part.

injuries sustained from a fall from the horse. ${ }^{35} 121517$ The reporting mechanism also varied, with some using injury report forms, ${ }^{74}$ insurance claims ${ }^{12}{ }^{15}$ or selfreported surveys ${ }^{11}$ to collect their data. The racetrack personnel responsible for completion of injury reports has varied among medical officials, ${ }^{5} 71117$ racetrack stewards ${ }^{312}$ and insurance brokers. ${ }^{14}$

Our study was based on incident reports completed by track-side primary care sports medicine physicians to include the broadest possible range of jockey injuries incurred while racing. Other recent studies have used more severe injury definitions, as when the jockey was unfit to ride or transported to the hospital ${ }^{12}$ or based on a fall or dislodging from the horse that required hospital transport. ${ }^{3}$ Studies based out of Europe have defined injury as one that leads to time off of work, ${ }^{11}$ while Balendra et al only examined careerending injuries. ${ }^{9}$ Additionally, some studies relied on jockey reporting of injuries, which can be affected by recall bias, wherein they are less likely to recall more minor injuries. ${ }^{13}$ Reporting bias may also contribute to under-reporting, since jockeys may be reluctant to miss any races, which can have a significant financial impact.

\section{Injury type}

The preponderance of soft tissue injuries $(80 \%)$ found in our study is consistent with O'Connor $e t a l^{7}$ which also relied on injury reports completed by their track medical officer. In contrast, the rate of fractures in our study (145 per 1000 falls) was 2.6 times higher than the study in Ireland, which may reflect the differences in track surfaces, race type (ie, flat vs jump) and jockey characteristics.

The proportion of injuries resulting in concussion (4\%) is comparable to a previous study from Press $e t$ al $(8 \%) .{ }^{13}$ In a 10 -year study published by McCrory et al comparing injuries in France, Ireland and Great Britain, ${ }^{5}$ concussions were $2.8 \%$ of total falls in Great Britain, $5.6 \%$ in France and $7.1 \%$ in Ireland. Concussion reporting and rates can vary significantly based on diagnostic standards and concussion protocols at each racetrack. With the rapid advancement in concussion management, 
Table 3 Mechanism of injury $(n=146)$

\begin{tabular}{lcc}
\hline Mechanism of injury & Frequency & Percentage \\
\hline Falls & & \\
\hline Thrown from horse & 34 & 23.3 \\
\hline Horse reared/flipped/spooked & 24 & 16.4 \\
\hline Horse breakdown & 24 & 16.4 \\
\hline Impact with gate/fence/rail & 17 & 11.6 \\
\hline Horse tripped/stumbled & 12 & 8.2 \\
\hline Fell over fallen horse & 7 & 4.8 \\
\hline Clipped heels & 6 & 4.1 \\
\hline Total & 124 & \\
Others & & \\
\hline Impact with horse & 11 & 7.5 \\
\hline Pulling up horse & 6 & 4.1 \\
\hline Unspecified & 3 & 2.1 \\
\hline Equipment failure & 1 & 0.7 \\
\hline Struck by object & 1 & 0.7 \\
\hline Total & 22 & 100 \\
\hline Total & 146 & \\
\hline
\end{tabular}

*Of the 11 instances of 'Impact with horse', 6 of those injuries were caused by being headbutted by horse.

reporting and protocols in the different regions are expected to progress. Future studies will more specifically evaluate concussion incidence in horse racing, which has been proposed to be one of the highest in sport. ${ }^{18}$

We identified a significant proportion of injuries $(41 \%)$ in and around the starting gate. This is comparable to Waller et al, who found $35.1 \%$ of their injuries occurring in and around the starting gate. ${ }^{14}$

Medical providers determine the appropriate level of care that the patient is transported to following a traumatic incident. We identified over a quarter of injuries required further medical care in a hospital or other medical facility. This is comparable to the study by Hitchens $e t$ al, who reported $30.6 \%$ of falls and resulted in the jockey being transported to the hospital. ${ }^{3}$

During training and racing, riders are required to wear properly secured safety helmets and vests meeting Association of Racing Commissioners International model rules and standards. Equestrian helmets have a tough outer shell, an energy-absorbing liner, comfort padding and a restraint system that keeps the helmet in place. Helmets are composed of an outer shell made from plastic, usually acrylonitrile butadiene styrene or a fibre-reinforced plastic composite and an energy absorbing liner usually made from expanded polystyrene or expanded polypropylene. ${ }^{18}{ }^{19}$ Standards of testing and regulations may vary among countries and ultimately may contribute to differences in injury rates among racing jurisdictions around the world.

The strength of this study was the use of a sports medicine model, which offered jockeys access to sports medicine specialists for immediate and follow-up evaluations without charge to the patient or workman's compensation. Ease of access to a consistent group of medical providers facilitated improved reporting, especially of minor injuries. In comparison, Turner et al recognised the limitations of relying on workers' compensation claims, which may not be filed if less than 1-3 days of work are lost. ${ }^{20}$

A primary limitation of our study was that the length of time to full recovery and pain-free function was not reported. Also, we were not able to associate risks of injury with jockey characteristics. The fluid movement of jockeys across racetracks was challenging to document jockeys' exposures.

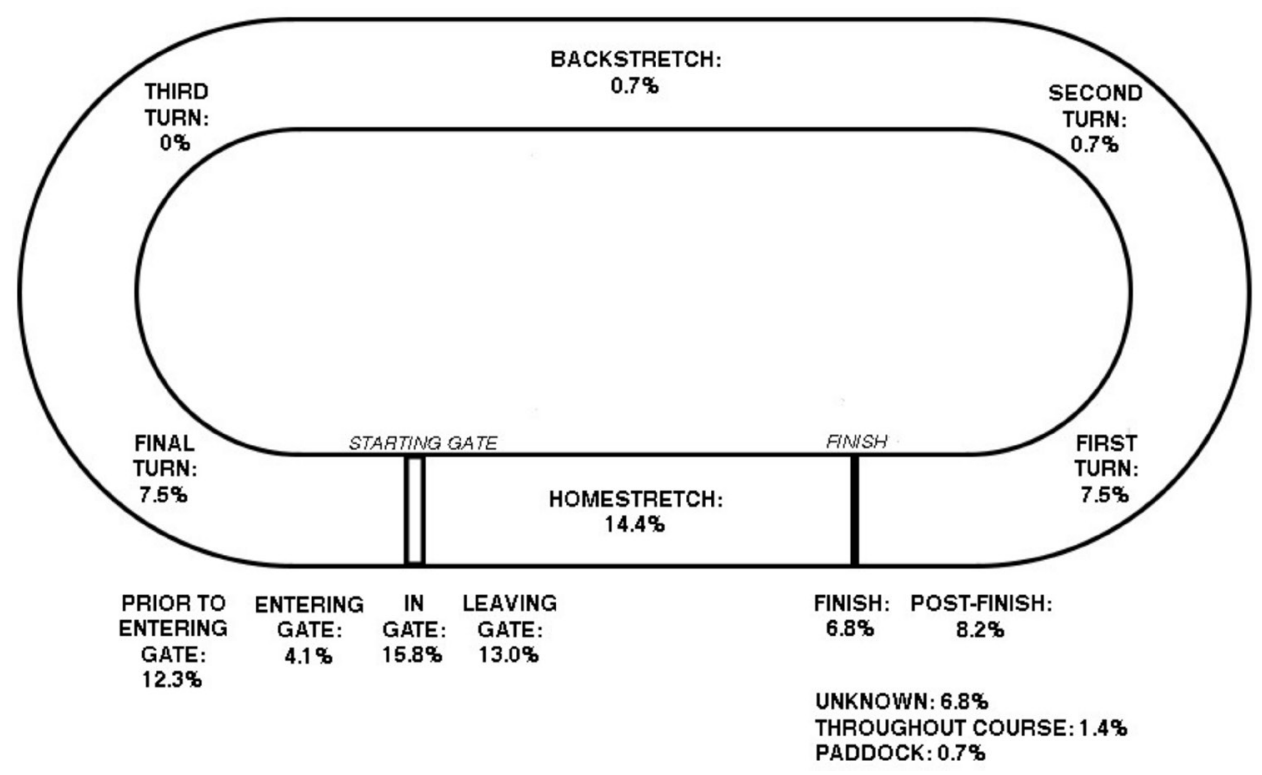

Figure 2 Location of injury on racetrack. 
The goal of this study was to characterise the rate, types and mechanisms of injury among jockeys at Maryland thoroughbred racetracks. Our hope is that more sports medicine clinicians coordinate care with local racetracks in the USA and that racing jurisdictions around the world, such as the British HorseRacing Authority, Irish Turf Club, the Palio di Siena, Australian Racing Board, The Hong Kong Jockey Club, the National Horseracing Authority of Southern Africa, and others will improve injury data collection to benefit riders' health and safety internationally.

Acknowledgements The authors would like to thank the Maryland Thoroughbred Horsemen's Association and the Maryland Jockey Club for their contributions to the development of the horsemen's health program and Dr Michael Turner for his guidance. The authors would also like to thank Diana Pinones for assistance with data collection.

Contributors AEL: conception of the study, study design, manuscript development. KR: conception of the study and contributed to study design, data collection and interpretation, manuscript development. GG: data collection and analysis. CMH: preparation of materials for IRB. KA: submitting materials for IRB, critical revision of the manuscript (AEL, KA, KR) and reviewed the document prior to submission.

Funding The authors have not declared a specific grant for this research from any funding agency in the public, commercial or not-for-profit sectors.

Competing interests None declared.

Patient consent for publication Not required.

Provenance and peer review Not commissioned; externally peer reviewed.

Data availability statement № data are available.

Open access This is an open access article distributed in accordance with the Creative Commons Attribution Non Commercial (CC BY-NC 4.0) license, which permits others to distribute, remix, adapt, build upon this work non-commercially, and license their derivative works on different terms, provided the original work is properly cited, appropriate credit is given, any changes made indicated, and the use is non-commercial. See: http://creativecommons.org/licenses/by-nc/4.0/.

ORCID iDs

Kezia Alexander http://orcid.org/0000-0003-0556-6997

Andrew E Lincoln http://orcid.org/0000-0003-2345-3320

\section{REFERENCES}

1 Cullen S, O'Loughlin G, McGoldrick A, et al. Physiological demands of flat horse racing Jockeys. J Strength Cond Res 2015;29:3060-6.

2 Madden C, Putukian M, McCarty E, et al. Rodeo and Equestrian Medicine. In: Netter's Sports Medicine. 2nd edn. Elsevier, 2017.
3 Hitchens PL, Hill AE, Stover SM. Jockey falls, injuries, and fatalities associated with thoroughbred and quarter horse racing in California, 2007-2011. Orthop J Sports Med 2013;1:232596711349262 https:// www.ncbi.nlm.nih.gov/pubmed/26535231

4 Filby M, Jackson C, Turner M. Only falls and horses: accidents and injuries in racehorse training. Occup Med 2012;62:343-9 https:// www.ncbi.nlm.nih.gov/pubmed/22764272

5 McCrory P, Turner M, LeMasson B, et al. An analysis of injuries resulting from professional horse racing in France during 1991-2001: a comparison with injuries resulting from professional horse racing in Great Britain during 1992-2001. Br J Sports Med 2006;40:614-8.

6 O'Connor S, Warrington G, Mb AM, et al. A 9-year epidemiologic study (2007-2015) on Race-Day Jockey fall and injury incidence in amateur Irish horse racing. J Athl Train 2018;53:950-5 https://www. ncbi.nlm.nih.gov/pubmed/30376371

7 O'Connor S, Warrington G, McGoldrick A, et al. Epidemiology of injury due to Race-Day Jockey falls in professional flat and jump horse racing in Ireland, 2011-2015. J Ath/ Train 2017;52:1140-6 https://www.ncbi.nlm.nih.gov/pubmed/29154693

8 Turner M, Fuller CW, Egan D, et al. European consensus on epidemiological studies of injuries in the thoroughbred horse racing industry. Br J Sports Med 2012;46:704-8.

9 Balendra G, Turner M, McCrory P. Career-ending injuries to professional jockeys in British horse racing (1991-2005). Br J Sports Med 2008;42:22-4.

10 Cowley S, Bowman B, Lawrance M. Injuries in the Victorian thoroughbred racing industry. Br J Sports Med 2007;41:639-43.

11 Rueda MAF, Halley WL, Gilchrist MD. Fall and injury incidence rates of jockeys while racing in Ireland, France and Britain. Injury 2010;41:533-9 https://www.clinicalkey.es/playcontent/1-s2.0S0020138309002708

12 Hitchens PL, Blizzard CL, Jones G, et al. The incidence of race-day jockey falls in Australia, 2002-2006. Med J Aust 2009;190:83-6 https://onlinelibrary.wiley.com/doi/abs/

13 Fortina M, Maniscalco P, Carulli C, et al. Jockey injuries during the Siena "Palio". A 72-year analysis of the oldest horse race in Italy. Injury 2019;50 Suppl 4:S56-9.

14 Waller AE, Daniels JL, Weaver NL, et al. Jockey injuries in the United States. JAMA 2000;283:1326-8.

15 Press JM, Davis PD, Wiesner SL, et al. The National jockey injury study: an analysis of injuries to professional horse-racing jockeys. Clin J Sport Med 1995;5:236-40 http://ovidsp.ovid.com/ovidweb. cgi? $T=J S \& N E W S=n \& C S C=Y \& P A G E=$ fulltext\&D=ovft\&AN=00042752199510000-00005

16 Hitchens PL, Blizzard CL, Jones G. Predictors of race-day jockey falls in flat racing in Australia. Occup Environ Med 2010;8:67-93.

17 Turner M, McCrory P, Halley W. Injuries in professional horse racing in Great britain and the Republic of Ireland during 1992-2000. Br J Sports Med 2002;36:403-9.

18 Turner M. Happy birthday concussion! Br J Sports Med 2019;53:203.

19 Connor TA, Clark JM, Jayamohan J, et al. Do Equestrian helmets prevent concussion? A retrospective analysis of head injuries and helmet damage from real-world Equestrian accidents. Sports Med Open 2019;5:19.

20 Turner M, Balendra G, McCrory P. Payments to injured professional jockeys in British horse racing (1996-2006). Br J Sports Med 2008;42:763-6. 